\title{
ПОНЯТТЯ ТА СУТНІСТЬ ОПЕРАТИВНОГО ПОШУКУ ЗЛОЧИННО-АКТИВНИХ ОСІБ ПІДРОЗДІЛАМИ КРИМІНАЛЬНОї ПОЛІЦІї
}

Дьоров С. Л.

\begin{abstract}
У науковій статті досліджено поняття та сутність оперативного пошуку злочинно-активних осіб підрозділами кримінальної поліціі. На підставі аналізу наявних поглядів, положень теорії оперативно-розшукової діяльності та результатів власного дослідження автор розкриває складові частини оперативного пошуку як організаційно-тактичної форми оперативно-розшукової діяльності, а також надає власне його визначення.

Ключові слова: оперативно-розшукова діяльність, оперативний пошук, кримінальна поліція, протидія злочинам, злочинно-активні особи.
\end{abstract}

В научной статье исследованы понятие и сущность оперативного поиска преступно-активных лиц подразделениями криминальной полиции. На основе анализа существующих точек зрения, положений теории оперативно-разыскной деятельности и результатов собственного исследования автор раскрывает составляющие оперативного поиска как организационно-тактической формы оперативно-разыскной деятельности, а также предоставляет его собственное определение.

Ключевые слова: оперативно-разыскная деятельность, оперативный поиск, криминальная полиция, противодействие преступлениям, преступно-активные лица.

Dorov S. L. The concept and essence of the operational search criminal-active personalities departments of the criminal police

The scientific article explores the concept and essence of the operational search criminal-active personalities departments of the criminal police. Based on the analysis of existing points of view, the provisions of the theory of operational search activity and the results of his own research, the author reveals the components of operational search as an organizational and tactical form of operational search activity, and also provides his own definition. The author, based on the provisions of criminal law, points out that persons who meet the requirements of the subjects of crimes, as well as prepare and commit intentional crimes, should be recognized as criminally active. The operational search of criminally active persons is one of the directions of realization of the form of operatively-search activity which consists in the organization and realization by operative workers of divisions of criminal police of a complex of open and covert actions, for the purpose of the decision of tasks of operatively-search activity, who have the characteristics of the subjects of the crime, and carry out actions for the preparation and commission of intentional criminal offenses. The article analyzes the main views of modern scientists in the field of the theory of operational investigative activity regarding organizational and tactical forms of such activity. The directions of the operational search in the activities of the criminal police are considered. The main components and objects of the operative search for criminal police are indicated. It is proved that the operational search for criminally active indi-

() Дьоров С. Л., 2020 viduals is one of the components and directions of the general operational search in the activities of the police. Based on the results of the study, the author gives specific suggestions for making changes and additions to existing regulatory legal acts in the field of combating crime.

Key words: operational-search activity, operational search, criminal police, counteraction to crimes, criminal-active personalities.

Постановка проблеми та їі актуальність. Результативна протидія злочинності в сучасних умовах потребує постійного отримання та використання актуальної оперативної інформації стосовно невідомих раніше фактів, подій і осіб, які готують та/або вчиняють кримінальні правопорушення. Оперативно-розшукові заходи, що здійснюють підрозділи кримінальної поліції, не $\epsilon$ сталою категорією, адже умови існування суспільства, технічний прогрес вимагають постійного оновлення та вдосконалення існуючого інструментарію протидії злочинності. Водночас початковим етапом процесу протидії злочинності, безсумнівно, $є$ пошукова діяльність, а саме оперативний пошук. Варто зазначити, що категорія «оперативний пошук» як організаційно-тактична форма оперативно-розшукової діяльності (далі - ОРД) як один із напрямів передбачає пошук злочинно-активних осіб. Однак в умовах сьогодення наукові розробки стосовно поняття та сутності такої діяльності потребують нових підходів. Саме цим і зумовлена актуальність зазначеної проблеми.

Аналіз останніх досліджень i публікацій. Проблемні питання, пов'язані з пошуком даних про осіб, факти й об'єкти матеріального світу, що становлять оперативний інтерес для суб'єктів ОРД у цілях протидії злочинності, тривалий час перебували та перебувають у колі наукової уваги, адже значущість пошукової роботи, що являє собою окрему форму оперативно-розшукової діяльності, разом з оперативно-розшуковою профілактикою й оперативною розробкою, постійно підтверджується відповідною практикою діяльності оперативних підрозділів Національної поліції. Окремим аспектам організації і тактики пошукової діяльності оперативних підрозділів Національної поліції України присвятили свої наукові праці такі сучасні дослідники, як: С.В. Албул, О.М. Бандурка, В.І. Василинчук, М.Л. Грібов, Е.О. Дідоренко, В.П. Захаров, О.І. Козаченко, Д.Й. Никифорчук, М.А. Погорецький, М.Б. Саакян, М.В. Стащак, В.Є. Тарасенко, В.В. Шендрик та інші. Водночас питання визначення поняття та сутності оперативного пошуку злочинно-активних осіб підрозділами кримінальної поліції, залишаються такими, що потребують удосконалення.

Метою статті $\epsilon$ визначення й аналіз сутності поняття оперативного пошуку злочинно-активних осіб підрозділами кримінальної поліції. 
Виклад основного матеріалу. Першочерговою стадією будь-якого процесу пізнання $\epsilon$ пошук. У теорії оперативно-розшукової діяльності він являє собою особливий вид, організаційно-тактичну форму, яка має назву «оперативний пошук». У межах організаційно-тактичних форм оперативно-розшукової діяльності реалізується комплексний характер оперативно-розшукових заходів, з урахуванням взаємопов'язаності яких, як стверджує О.М. Бандурка, можна цілком об'єктивно говорити про взаємозв'язок і взаємопроникнення форм оперативно-розшукової діяльності [1, с. 115]. У цьому сенсі ми підтримуємо думку С.В. Албула, який визначає оперативний пошук як форму оперативно-розшукової діяльності, що являє собою систему оперативно-розшукових заходів, які організовуються і здійснюються оперативними підрозділами Національної поліції з метою виявлення первинних даних про осіб, предмети і факти, що становлять оперативний інтерес [2, с. 143].

У теорію ОРД термін «пошукова діяльність» був уведений у 70-ті рр. минулого сторіччя. До того вона визначалась як діяльність зі встановлення осіб і фактів, що становлять оперативний інтерес. Пошук та виявлення осіб і фактів, які становлять оперативний інтерес, визначався як один з основних в оперативно-розшуковій діяльності суб'єктів ОРД і фактично передбачав отримання та перевірку первинної інформації про комплекс об'єктів оперативної уваги. Ми поділяємо думку стосовно того, що основне організаційно-тактичне призначення його становить здійснення системи заходів поза зв'язком із конкретною особою чи фактом, у чому і виявляється одна 3 основних відмінностей даної форми від оперативної розробки, а також від проведення заходів, не пов'язаних з іншими справами оперативного обліку, які завжди ведуться за конкретними фактами щодо конкретних осіб [3, с. 5].

У теорії і практиці ОРД оперативний пошук осіб, предметів і фактів розглядається як самостійна форма оперативно-розшукової діяльності, якій притаманна низка ознак. У сукупності ці ознаки дають уявлення про сутність оперативного пошуку і його місце в системі оперативно-розшукової діяльності кримінальної поліції. Це свого роду фундамент такої діяльності, без якого неможливо успішно вирішувати завдання щодо боротьби зі злочинністю. Характерними рисами такого пошуку (виявлення) $є$ :

1. Здійснення не лише у зв'язку з учиненим злочином, а й незалежно від кримінальної події. Це характеризує оперативний пошук як ініціативну, активну дію, відмінну від інших оперативно-розшукових заходів, що здійснюються стосовно конкретних злочинів та осіб, які підозрюються у злочинній діяльності. Ініціативний оперативний пошук сприяє як ефективному оперативному обслуговуванню об'єктів, території, так і розслідуванню злочинів, зокрема й за межами зони обслуговування.

2. Проведення в його межах розвідувальних заходів $\epsilon$ не лише правом, а й одним з основних обов'язків кримінальної поліції. Застосовувані водночас заходи мають утворювати єдину пошукову систему, що охоплює всю обслуговувану підрозділом поліції територію. Оперативний пошук проводиться цілеспрямовано, на підставі вивчення й оцінки оперативної обстановки і становить вид оперативно-розшукового провадження, здійснюваного у формі виявлення і перевірки осіб, підозрюваних у вчиненні злочинів.
3. Комплексне здійснення в його межах заходів із розвідувальною спрямованістю. Водночас у вирішенні пошукових завдань беруть активну участь інші підрозділи поліції, однак головна роль належить оперативно-розшуковим підрозділам відповідно до їхньї компетенції та спеціалізованих завдань щодо боротьби зі злочинністю.

Отже, сутність оперативного пошуку полягає в тому, що він $€$ різновидом ініціативної, активної розвідувальної (за характером) діяльності оперативних підрозділів кримінальної поліції, що здійснюється не тільки у зв'язку з учиненим злочином, а й незалежно від кримінальної події. Інакше кажучи, сутністю оперативного пошуку $\epsilon$ оперативне пізнання криміногенних фактів, подій, осіб, предметів та речей, які мають ознаки злочинної діяльності або містять явні сліди злочину i ï необхідно розпізнати. Оперативний пошук спрямований на виявлення серед великої кількості однорідних об'єктів пошуку саме того, що стосується ознак певного злочину.

За слушним твердженням науковців, значення оперативного пошуку полягає в тому, що за допомогою комплексу цілеспрямованих заходів, здійснюваних суб'єктами оперативно-розшукової діяльності, виявляються, перевіряються і накопичуються відомості, які містять нові (раніше невідомі поліції) спеціальні знання, що мають значення під час вирішення завдань боротьби зі злочинністю [4, с. 32]. Оперативний пошук забезпечує вирішення таких основних завдань:

виявлення злочинних намірів окремих осіб та їх груп, своєчасне застосування засобів профілактичного впливу;

своєчасне отримання інформації про злочини, що готуються, уживання заходів щодо запобігання їм;

своєчасне отримання інформації про вчинені злочини, уживання заходів щодо встановлення і викриття винних;

- забезпечення прав та інтересів громадян, державних і громадських організацій виявленням і вилученням викраденого майна;

отримання інформації, необхідної для аналізу й оцінки оперативної обстановки на території обслуговування, і вжиття заходів щодо оптимальної розстановки сил для активізації боротьби із правопорушниками [4, с. 92].

Аналіз наукової літератури, емпіричних даних і практичний досвід боротьби зі злочинністю дозволяють виділити основні об'єкти оперативного пошуку. Це особи, предмети і події (факти), що можуть бути причетні або безпосередньо причетні до вчинення злочинів, учинюють їх (наприклад, особи, що готують або вчинили злочин), а також дають підстави стверджувати про його вчинення 3 достатнім ступенем імовірності. Тобто це особи, які мають ознаки, що характеризують їхню злочинну настанову, задуми, дії і факти, ознаки яких свідчать про можливість або наявність злочинних дій, причин, що породжують злочини, і умов, які сприяють їх учиненню.

Предмети і документи, що становлять оперативний інтерес, це вилучені з обігу речі (зброя, вибухівка, наркотики, отруйні речовини), фальшиві гроші, підроблені документи, викрадене майно, цінності тощо. До предметів, що мають пошукове значення, належать, наприклад, знаряддя злому, використовувані під час 
учинення крадіжок, зброя й інші предмети, залишені злочинцем на місці вчинення злочину, одяг і взуття, що були на ньому. До цієї ж категорії варто віднести й усі інші матеріальні об'єкти, які свідчать про наявність злочину або причетність до нього конкретних осіб, незалежно від можливості використовувати ці об'єкти як докази [2, с. 143].

До подій (фактів), які становлять оперативний інтерес, відносять явища, обставини, що існували в реальному житті, а інформація про них має значення для досягнення мети оперативно-розшукової діяльності, але до поліції не надходила. Це відомості про підготовлювані та вчинені злочини, появу злочинця, який розшукується, зустрічі криміногенного елементу, злочинні «розбірки», формування протиправних угруповань, створення умов для полегшення і маскування злочинної діяльності тощо [2, с. 144].

Проведений нами аналіз емпіричного матеріалу дає можливість стверджувати, що оперативний пошук злочинно-активних осіб підрозділами кримінальної поліції не обмежується тільки проведенням саме пошукових заходів, а також містить комплекс заходів щодо перевірки, накопичення, аналізу інформації, яка має значення для вирішення завдань боротьби зі злочинністю. Цей комплекс заходів можна порівняти із внутрішнім змістом оперативного пошуку злочинно-активних осіб, з їі інформаційним наповненням. Тому ми вважаємо, що оперативний пошук може бути спрямований на будьяку первинну інформацію, яка охоплює певний простір у визначений час.

Варто наголосити, що натепер у теорії оперативно-розшукової діяльності немає єдиної думки щодо поняття, сутності та складових елементів оперативного пошуку, зокрема щодо оперативного пошуку злочинно-активних осіб підрозділами кримінальної поліції. Теоретики в галузі ОРД висловлюють різні думки щодо сутності оперативного пошуку. Деякі вчені порівнюють оперативний пошук суто з особистим пошуком. Деякі дотримуються думки, що проведення пошукової роботи передбачає організацію оперативного спостереження за об'єктами, що становлять оперативний інтерес, яке здійснюється за допомогою особистого пошуку.

Прихильники розуміння особистого пошуку як самостійного методу оперативно-розшукової діяльності розглядають його як такий, що охоплює гласні чи негласні дії, які здійснюються безпосередньо оперативним працівником кримінальної поліції шляхом застосування комплексу практично всіх наявних прийомів і методів ОРД із метою виявлення кримінального елементу, попередження і розкриття злочинів [1, с. 174].

3 огляду на предмет нашого дослідження слушною, на наш погляд, $є$ думка О.І. Козаченка, який, розкриваючи сутність пошукових заходів, зазначав, що це дії оперативних працівників щодо встановлення ще невідомих правоохоронним органам подій злочину і осіб, злочинів, що готуються або вчинені невстановленими особами [5, с. 263].

Більш розгорнуте визначення оперативного пошуку надає В.В. Колосков, який уважає, що таким є «система гласних і негласних організаційних та оперативних заходів, спрямованих на отримання первинної, ще невідомої правоохоронним органам інформації, з метою запобігання фактам або ознакам про вчинені злочини $\mathrm{i}$ ті, що готуються, виявлення таких, а також одержання відомостей щодо осіб, які можуть бути причетними до протиправної діяльності» [6, с. 28].

Таке визначення цілком відповідає законодавчій дефініції «оперативно-розшукової діяльності» та їі тлумаченню. У ст. 2 Закону України «Про оперативно-розшукову діяльність» під оперативно-розшуковою діяльністю розуміється «система гласних і негласних пошукових (курсив наш - С. Д.), розвідувальних та контррозвідувальних заходів, що здійснюються із застосуванням оперативних та оперативно-технічних засобів» [7]. У свою чергу, відповідно до ст. 23 Закону України «Про Національну поліцію» поліція відповідно до покладених на неї завдань, серед іншого: виявляє причини й умови, що сприяють учиненню кримінальних правопорушень, уживає у межах своєї компетенції заходів для їх усунення; уживає заходів із метою виявлення кримінальних правопорушень; припиняє виявлені кримінальні й адміністративні правопорушення [8]. У зв'язку із цим варто погодитись з авторами посібника «Основи оперативно-розшукової діяльності в Україні», які слушно вказують на те, що «оперативно-розшукова діяльність суттєво відрізняється від будьяких інших видів діяльності та має яскраво виражений розвідувально-пошуковий характер. Так, усі їі заходи законодавчо визначаються як пошукові, розвідувальні та контррозвідувальні. Водночас пошукові заходи - це дії працівників оперативних підрозділів щодо встановлення ще невідомих подій злочину й осіб, які причетні до їх учинення, а також злочинів, що готуються або вчинені невстановленими особами» [9, с. 32-33].

Отже, варто зосередити увагу на тому, що сутність оперативного пошуку полягає, на наше переконання, саме у виявленні, встановленні раніше невідомих фактів, явищ та злочинно-активних осіб.

Теоретики, які розглядають поняття оперативного пошуку, визначають його як проведення оперативним працівником оперативно-розшукових заходів шляхом особистого застосування засобів і методів оперативно-розшукової діяльності з метою боротьби зі злочинністю [1, с. 201]. Водночас змістовна сторона оперативного пошуку, за твердженням науковців, передбачає застосування прийомів оперативного розпізнавання, оперативного спостереження, оперативної установки, оперативного огляду, розвідувального опитування й агентурного методу. Тобто оперативний пошук розглядається не як самостійний метод оперативно-розшукової діяльності, а як організаційно-тактична форма застосування спеціальних методів безпосередньо оперативним працівником у вирішенні окремих оперативно-службових завдань [3, с. 5].

Як нами зазначалося, оперативний пошук передбачає отримання та перевірку первинної інформації про осіб та факти, що становлять оперативний інтерес, поза зв'язком із конкретною особою чи фактом, з подальшим виокремленням їх із загальної маси. У цьому - одна з головних відмінностей оперативного пошуку від заходів за матеріалами оперативної розробки, які завжди проводяться за конкретними фактами чи щодо конкретних осіб. Як система організації оперативний пошук має власні, особливі ознаки, що відрізняють його від інших форм оперативно-розшукової діяльності. До таких ознак можна віднести такі:

здійснення цієї діяльності поза зв'язком із фактами й особами, які вже відомі; 
- його організація в місцях найбільш вірогідного виявлення ознак і об'єктів, що встановлюються;

- підстави для його проведення; систематичність здійснення.

Найважливішою рисою, що визначає сутність оперативного пошуку, $\epsilon$ перелік даних, які підлягають виявленню. До них, на думку науковців, належать відомості про:

- факти готування і вчинення злочинів;

- інші обставини, що мають значення для боротьби зі злочинністю (зокрема, характеристики злочинів і осіб винних; причини й умови, що сприяють учиненню злочинів);

- сліди і знаряддя готування до злочину;

- сліди, залишені злочинцями на місці події;

знаряддя вчинення злочинів; викрадене майно

й інші предмети, що мають значення для встановлення і викриття винних осіб;

- предмети і речовини, заборонені для зберігання, носіння або користування;

- осіб, що замислюють, готують чи вчинили злочин, або причетних до нього осіб;

- осіб із протиправною поведінкою, яка свідчить про можливість учинення ними злочинів;

- осіб, яким відома інформація, що має значення для боротьби зі злочинністю.

Законодавчі та відомчі нормативні акти не містять визначення поняття «злочинно-активні особи». Водночас теорія оперативно-розшукової діяльності оперує такими визначеннями, як «особи, які становлять оперативний інтерес», «особи, від яких можна очікувати вчинення злочинів» тощо. На нашу думку, злочинно-активними варто вважати осіб, які готують та вчинюють умисні злочини. Надаючи таке визначення, неможливо не звернутися до питань теорії кримінального права та кримінології. Спираючись на положення чинного кримінального законодавства, можна стверджувати, що поняття кримінальної активності напряму пов'язане саме з умисною формою вини, адже саме умисел передбачає активні дії особи. Крім цього, така активність може являти собою дії підготовчого характеру та замаху на вчинення злочину. Отже, злочинна активність $€$ проявами активної діяльності осіб, які мають ознаки суб'єкта злочину, щодо готування та вчинення умисних кримінальних правопорушень. На наш погляд, злочинно-активні особи - це особи, які мають ознаки суб'єктів злочину, здійснюють дії щодо готування та вчинення умисних кримінальних правопорушень.

Висновки. Якщо підсумувати наведені думки науковців, положення чинних нормативних актів, виходити з усвідомлення загальної теорії оперативно-розшукової діяльності, то можна, на наш погляд, надати власне визначення поняття «оперативний пошук зло- чинно-активних осіб підрозділами кримінальної поліції». Оперативний пошук злочинно-активних осіб - це один із напрямів реалізації форми оперативно-розшукової діяльності, який полягає в організації та здійсненні оперативними працівниками підрозділів кримінальної поліції комплексу гласних та негласних дій із метою вирішення завдань оперативно-розшукової діяльності, спрямованих на виявлення та встановлення осіб, які мають ознаки суб'єктів злочину, здійснюють дії щодо готування та вчинення умисних кримінальних правопорушень.

\section{Література}

1. Бандурка О.М. Теорія і практика оперативно-розшукової діяльності : монографія. Харків : Золота миля, 2012. 620 с.

2. Албул С.В. Оперативний пошук як організаційно-тактична форма оперативно-розшукової діяльності кримінальної поліції України: поняття та сутність. Scientific bases of solving of the modern tasks : Abstracts of XIX international scientific and practical conference. Frankfurt am Main, Germany, 2020. P. 138-144.

3. Албул С.В. Поняття та складові оперативного (ініціативного) пошуку підрозділів карного розшуку. Організаційно-правові засади боротьби з правопорушеннями на транспорті : матеріали Всеукраїнської науково-практичної конференції, м. Одеса, 29 листопада 2013 р. Одеса : ОДУВС, 2013. С. 4-5.

4. Особливості отримання і використання первинної оперативно-розшукової інформації підрозділами карного розшуку : монографія / М.Д. Мартинов та ін. Київ : ДП «Розвиток», 2012. 232 c.

5. Козаченко О.І. Інститут негласного співробітництва: теорія і практика : монографія. Київ : ДП «Розвиток», 2020. 1105 c.

6. Колосков В.В. Щодо визначення понять оперативний пошук і оперативний розшук. Актуальні проблеми взаємодії оперативних та слідчих підрозділів у протидії організованій злочинній діяльності : матеріали Всеукраїнської науково-практичної конференції, м. Одеса, 18 квітня 2008 р. Одеса : ОДУВС, 2008. С. 27-29.

7. Про оперативно-розшукову діяльність : Закон України від 18 лютого 1992 р. № 2135-XII, зі змін. URL: http://zakon1.rada.gov.ua (дата звернення: 12.06.2020).

8. Про Національну поліцію : Закон України від 2 липня 2015 р. № 580-VIII. URL: http:/ / zakon1.rada.gov.ua (дата звернення: 12.06.2020).

9. Основи оперативно-розшукової діяльності в Україні : навчальний посібник / В.В. Аброськін та ін. ; за ред. В.В. Аброськіна. Одеса : ОДУВС, 2020. 290 с.

Дьоров С. Л., ад’юнкт кафедри оперативно-розшукової діяльності факультету підготовки фахівців для підрозділів кримінальної поліціі одеського державного університету внутрішніх справ 